\title{
Effects of cross-sectional shape on the bending strength in furniture
}

\section{joints}

\author{
Mehmet ACAR ${ }^{1 *}$, Harun DİLER ${ }^{2}$, Yusuf Ziya ERDİL ${ }^{1}$
}

${ }^{1}$ Mugla S.K. University, Department of Wood Products Industrial Engineering, 48000, Muğla, TURKEY

${ }^{2}$ Akdeniz University, Dept. of Material and Material Processing Technologies, 70000, Antalya, TURKEY

*Corresponding author: macar@mu.edu.tr

Received Date: 06.10.2017

Accepted Date: 08.06.2018

\begin{abstract}
Aim of the study: Tests were carried out to evaluate the ultimate bending strength of the circular and square cross sectioned furniture joint members and find out whether the form factor is applicable to the small specimens as they are applied to large specimens and compare the maximum bending strength and specific gravity values of these wood species to those that are specified in reference books.

Material and methods: The specimens were prepared from Red oak (Quercus rubra), Yellow poplar (Liriodendron tulipifera), Southern pine (Pinus sp.), Caobilla (Carapa guianensis), and Gmelina (Gmelina arborea). Based on five wood species by five replications, 25 square cross sectional ( $25 \mathrm{x} 25$ $\mathrm{mm}$ ) specimens and 25 specimens which included $19 \mathrm{~mm}$ diameter circular mortise and tenon joints, a total of 50 specimens were prepared and tested under the static bending test according to related standards.

Main results: Results gave the primary indication that the form factor of 1.18 from square to circular cross section is applicable to small clear specimens; however, it should be noted that absolute conclusions require studies in much wider spectrum.

Research highlights: The results of this study indicate that designers and furniture engineers may obtain good estimates from 1.18 form factor and comparison of MOR values and specific gravity of the wood species with the book values.

Keywords: Bending strength, joint, wood, circular tenon

\section{Yuvarlak ve kare kesitli mobilya bağlantı elemanlarının eğilme}

\section{direncinin karşılaştırılması}

Özet

Çalışmanın amacı: Bu çalışma, dairesel ve kare kesitli mobilya bağlantı elemanlarının maksimum eğilme mukavemetinin değerlendirilmesi ve küçük test örneklerine uygulanan şekil faktörünün büyük test örneklerine uygulandığında uygulanabilirliğinin değerlendirilmesi ve kullanılan ağaç türlerine ilişkin maksimum eğilme mukavemeti ve özgül ağırlı değerlerinin referans kitaplarda verilen değerler ile karşılaştırılması amaçlanmıştır.

Materyal ve Metot: Test örneklerinin hazırlanmasında kızıl meșe (Quercus rubra), sarı kavak (Liriodendron tulipifera), çam (Pinus sp.), caobilla (Carapa guianensis), and gmelina (Gmelina arborea) ağaç türleri kullanılmıştır. Beş ağaç türü ve beş tekrardan oluşan toplam 25 kare kesitli $(25 \times 25 \mathrm{~mm})$ ve 19 $\mathrm{mm}$ çapında yuvarlak zıvana bağlantısı uygulanan diğer 25 test örneği olmak üzere toplam 50 test örneği ilgili standartlara göre statik yük altında test edilmiştir.

Sonuçlar: Sonuçlar göstermiştir ki köşeli kesitten yuvarlak kesite 1.18 katsayısı kullanılarak küçük test örneklerine uygulama yapılabilir ancak belirtmek gerekir ki kesin sonuçlar için daha geniş kapsamlı çalışmalara ihtiyaç duyulmaktadır.

Önemli vurgular: Bu çalışmanın bir sonucu olan 1.18 katsayısının ve ayrıca özgül ağırlık ve eğilme direnci değerlerinin referans kitap değerleri ile karşılaştırma sonuçlarının, mobilya mühendisleri ve tasarımcıları tarafından tasarım süreçlerinde kullanılabileceği söylenebilir.

Anahtar Kelimeler: Eğilme mukavemeti, bağlantı, ahşap, yuvarlak zıvana 


\section{Introduction}

As it is expected, circular mortise and tenon joints are the key points of failure in furniture such as chair and desk frames. Front to back and side thrust loads on the frames puts high bending forces on the ends of the members where the circular mortise and tenons are located. The cross-sectional properties of members are important in terms of resistance to bending. Published literature and basic engineering formulas indicate that circular cross sections are having 18 percent more stress than predicted by conventional bending stress expressions for square cross sections (Markwardt and Wilson, 1935). For example, a round beam with $1 \mathrm{~mm}^{2}$ crosssectional area has a bending strength of,

$$
\sigma=\frac{32 \cdot M}{\pi \cdot D^{3}}=7.097 \cdot M
$$

where,

$\sigma=$ bending stress $\left(\mathrm{N} / \mathrm{mm}^{2}\right)$,

$\pi=3.1416$ constant ,

$M=$ Bending moment at the point of stress $(\mathrm{N} / \mathrm{mm})$,

$D=$ Diameter of round cross section $(\mathrm{mm})$

$$
I=\frac{\pi D^{4}}{64}\left(\mathrm{~mm}^{4}\right)
$$

On the other hand, a comparable rectangular cross-section with $1 \mathrm{~mm}^{2}$ crosssectional area has a bending strength of,

$$
\sigma=\frac{M c}{I}=6 \cdot M
$$

where,

$\sigma=$ bending stress $\left(\mathrm{N} / \mathrm{mm}^{2}\right)$,

$M=$ Bending moment at the point of stress $(\mathrm{N} / \mathrm{mm})$

$c=$ Distance from neutral axis $(\mathrm{mm})$,

$I=$ Rectangular cross-sectional area moment of inertia,

$$
I=\frac{b h^{3}}{12}\left(\mathrm{~mm}^{4}\right)
$$

Tests carried out by Markwardt and Wilson (1935) also suggested that a beam of given cross-sectional area carries the same amount of load regardless of whether the cross section is circular, square, or diamond shape (diagonally loaded square). The comparable bending stresses from common square cross-section stress formula are 18 percent and 41 percent higher from the circular and diamond cross sections, respectively. Therefore, a 1.18 form factor may be applied to circular cross section and 1.41 to diamond cross section.

According to Wolfe et al. (2001), form factor referred to the correction factor from bending strength of square cross-sectional members to circular cross sections. They also referred to the study of Newlin and Trayer (1924) which has found that even though circular cross sections have 18 percent smaller section modulus $(\mathrm{I} / \mathrm{c})$, bending strength of them are equal to that of square cross section members.

Erdil et. al. (2005) investigated effect of tenon depth and tenon length on bending strength and flexibility of mortise and tenon T-type end to side grain joints. They referred that mortise and tenon joints become stiffer as either tenon length or tenon depth is increased.

Eckelman et. al. (2002) suggested that the intersecting holes reduce strength on school chair and table constructions by two-thirds or more. According to result of their study, ultimate bending moment of legs with intersection can be computed as a function of the compressive strength of the wood, whereas the ultimate bending moment of legs with cross holes spaced 1-1/2 inches apart can be estimated as a function of the bending strength of the wood.

Efe et. al., (2005) compared traditional adhesive-based dowel and mortise-tenon joints with alternative non-adhesive based joints as minifix plus dowel and screw joints. They obtained highest bending moment capacity from traditional adhesive-based joints as compare with alternative minifix plus dowel and screw joints.

Wood is a very variable material and for many of its parameters, such as density, cell length and microfibrillar structure, different variations could be consisted within a growth ring etc. All these variations effect the mechanical properties of the material. (Dinwoodie, 2000). 
Wood density is a measure of the cell wall material per unit volume and as such gives a very good indication of the strength properties and expected pulp yields of timber (Philips, 1941). Basic density is directly related with end-use quality parameters and structural timber strength (Harvald \& Olesen, 1987). Cown (1992) described that the density of wood is recognized as the key factor influencing wood strength. According to Schniewind (1989) a variation in wood strength, both between and within species, can be attributed to differences in wood density.

Modulus of rupture (MoR), reflects the maximum load carrying capacity of a member in bending and is proportional to maximum moment borne by the specimen. Modulus of rupture is an accepted criterion of strength, although it is not a true stress because the formula by which it is computed is valid only to the elastic limit. (Wood Handbook, 1999)

The main objective of this study was to find out whether the form factor of 1.18 is applicable to the bending strength of relatively small circular cross section members utilized in furniture members. Another purpose was to compare the maximum bending strength and specific gravity values of these wood species to those that are specified in reference books.

\section{Materials and Method}

Five distinct wood species were included in the study which are namely Red oak (Quercus rubra), Yellow poplar (Liriodendron tulipifera), Southern pine (Pinus sp.), Caobilla (Carapa guianensis), and Gmelina (Gmelina arborea).

Two set of test specimens were prepared. First set of test specimens were prepared and tested in three-point static bending test in accordance with the ASTM standard D14394 (2000); static bending, standard test methods of testing the small clear specimens of timber. The total specimen set included five wood species by five replications, i.e., 25 specimens. The dimensions of each test specimen was $25 \times 25 \times 410 \mathrm{~mm}$. The tests were conducted on a 133.4-kN capacity screw-powered universal testing machine. The test span was $360 \mathrm{~mm}$. and loading rate was $1,27 \mathrm{~mm} / \mathrm{min}$. The specimens were loaded at center point by a standard bearing block (Figure 1) and the loading was continued until a nonrecoverable drop-off in load occurred.

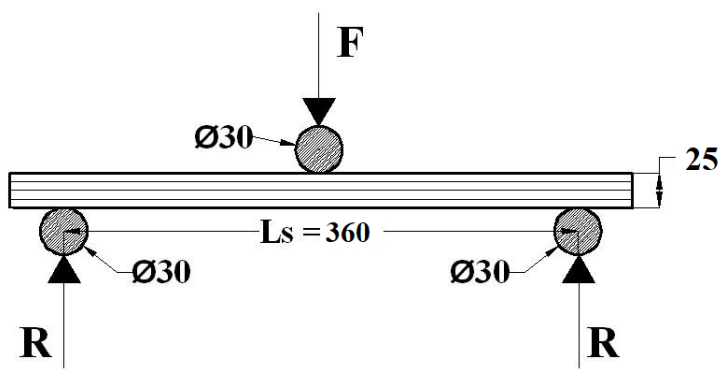

Figure 1. Three-point static bending test setup

Another set of specimens included the circular mortise and tenon joints. The total specimen set included five wood species by five replications, i.e., 25 specimens. The construction of the test specimens is shown in Figure 2.

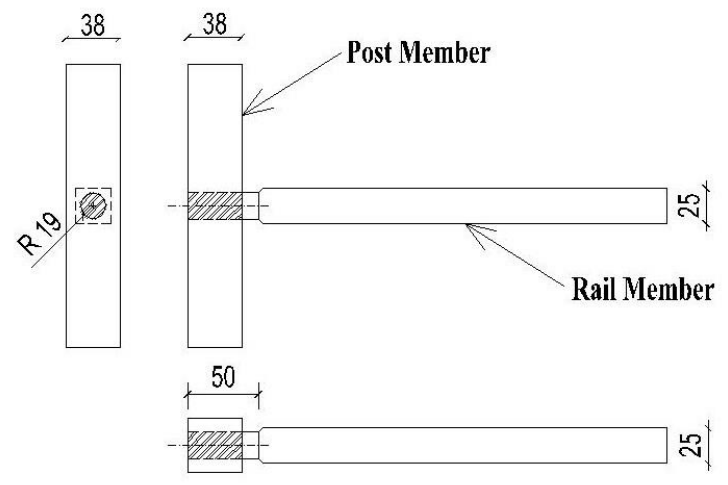

Figure 2. The configuration of circular mortise and tenon joint test specimen

The test specimens were consisted of two members, rail member and post member. The cross sections of rail post members were $38 \times 38 \mathrm{~mm}$, the cross section of rail members were $25 \times 25 \mathrm{~mm}$. Both post member and rail member had free length. Mortises were machined with a standard mortising chisels on a drill press. Tenons were created with a deep hole saw by $19 \mathrm{~mm}$ in diameter and inserted without adhesive into $19 \mathrm{~mm}$ in diameter mortises throughout the post member. 
The tests were conducted on a $133.4-\mathrm{kN}$ capacity screw-powered universal testing machine with $1,27 \mathrm{~mm} / \mathrm{min}$ loading rate. Specimens were attached to the testing specimen holder with two bolts (Figure 3). These specimens were loaded with a standard bearing block with a distance of $254 \mathrm{~mm}$ from outer edge of the mortise (Figure 3).

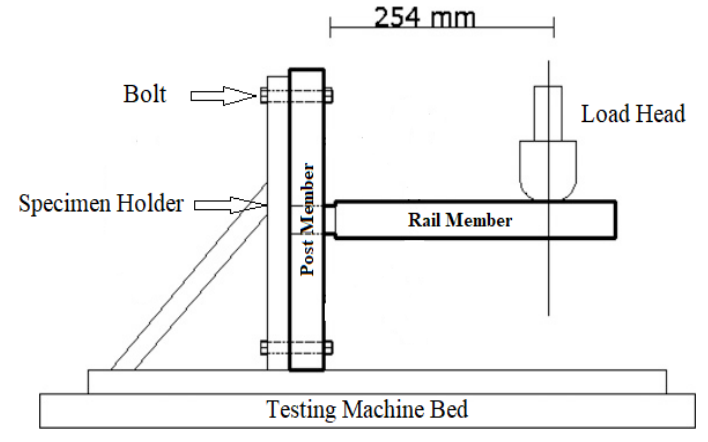

Figure 3. The configuration of the circular members bending set-up

A total of 50 specimens were tested. To reach desired equilibrium moisture content (EMC), the entire test specimens were held in a controlled environment where set to produce 7 percent EMC 5 days prior to testing. A total of 50 representative samples were taken from each specimen in order to determine the moisture content and specific gravity in accordance ASTM D 4442-92 (2001). Specimens were measured $25 * 25 * 25$ $\mathrm{mm}$.

Analyses of variance test (ANOVA) was performed to determine the differences among the factors. Least Significant Difference (LSD) test was used to determine if there was a meaningful difference among the groups.

\section{Results and Discussion}

Even though the specimens were held in a controlled environment set to produce 7 percent emc, the moisture content values varied within and between the wood species. According to Wood Handbook (1987), in adjusting the modulus of rupture (MOR) values, the 4 percent increase in bending strength with each 1 percent decrease in moisture content is suggested; this convention was utilized in this study (Chudnoff, 1984). Both square and circular cross-sectional specimen test results were adjusted to 12 percent moisture content in order to make comparison with the Wood Handbook (1987) values as well as from cross section to cross section or wood species to wood species. The comparison results were given in Table 1.

Table 1. Test results with compared to book values

\begin{tabular}{|c|c|c|c|c|c|c|c|c|c|}
\hline \multirow{2}{*}{$\begin{array}{l}\text { Wood } \\
\text { Species }\end{array}$} & \multicolumn{3}{|c|}{ Specific Gravity $\left(\mathrm{g} / \mathrm{cm}^{3}\right)$} & \multicolumn{3}{|c|}{$\begin{array}{c}\text { Modulus of Rupture }\left(\mathrm{N} / \mathrm{mm}^{2}\right) \\
\text { @ } 12 \% \mathrm{MC} \\
\end{array}$} & \multirow{2}{*}{$\begin{array}{l}\text { Square/ } \\
\text { Circular }\end{array}$} & \multicolumn{2}{|c|}{$\begin{array}{c}\% \text { Differences from } \\
\text { book value }\end{array}$} \\
\hline & Test value & Book value * & $\%$ Diff. & Book Value * & Square & $\overline{\text { Circular }}$ & & Square & Circular \\
\hline R. oak & $\begin{array}{l}0.72 \\
(13)\end{array}$ & $\begin{array}{l}0.63 \\
(10) \\
\end{array}$ & 5.3 & $\begin{array}{l}98.6 \\
(16) \\
\end{array}$ & $\begin{array}{c}115.4 \\
(23)\end{array}$ & $\begin{array}{c}117.5 \\
(26)\end{array}$ & 0.98 & 17.0 & 19.1 \\
\hline S. pine & $\begin{array}{c}0.57 \\
(9)\end{array}$ & $\begin{array}{l}0.51 \\
(10)\end{array}$ & 11.8 & $\begin{array}{l}88.3 \\
(16)\end{array}$ & $\begin{array}{c}104.5 \\
(13)\end{array}$ & $\begin{array}{l}109 \\
(12)\end{array}$ & 0.96 & 18.4 & 23.5 \\
\hline $\begin{array}{c}\text { Y. } \\
\text { poplar }\end{array}$ & $\begin{array}{c}0.47 \\
(5)\end{array}$ & $\begin{array}{l}0.42 \\
(10)\end{array}$ & 12.5 & $\begin{array}{l}69.7 \\
(16) \\
\end{array}$ & $\begin{array}{c}85.9 \\
(6)\end{array}$ & $\begin{array}{c}82.8 \\
(8)\end{array}$ & 1.04 & 23.4 & 18.8 \\
\hline Caobilla & $\begin{array}{c}0.56 \\
(5)\end{array}$ & $\begin{array}{l}0.56 \\
(10)\end{array}$ & -0.1 & $\begin{array}{c}107.7 \\
(16)\end{array}$ & $\begin{array}{c}110.5 \\
(11)\end{array}$ & $\begin{array}{l}107 \\
(13)\end{array}$ & 1.03 & 2.5 & -0.6 \\
\hline Gmelina & $\begin{array}{c}0.38 \\
(5)\end{array}$ & $\begin{array}{l}0.41 \\
(10)\end{array}$ & -8.4 & $\begin{array}{l}59.7 \\
(16)\end{array}$ & $\begin{array}{l}61.8 \\
(7)\end{array}$ & $\begin{array}{l}67 \\
(5)\end{array}$ & 0.92 & 3.7 & 12.5 \\
\hline
\end{tabular}

*Values from Wood Handbook, Values in parentheses are the Coefficients of Variations.

In general, the experimental results gave higher values than the Wood Handbook (1987) values of MOR for all wood species and cross sections except circular result of Caobilla. According to Table 1, the Red oak (Quercus rubra) specimens had the highest MOR of approximately $117 \mathrm{~N} / \mathrm{mm}^{2}$ in both circular and square cross-section tests while Gmelina (Gmelina arborea) had the lowest MOR of approximately $62 \mathrm{~N} / \mathrm{mm}^{2}$. It is clearly seen on the table that there is a linear interaction between specific gravity and MOR values. Higher density species tend to have stronger timber than lower density 
species (Addis Tsehaye et al., 1995b; Walker and Butterfield, 1996). Results showed that specific gravity has considerable influence onMOR.

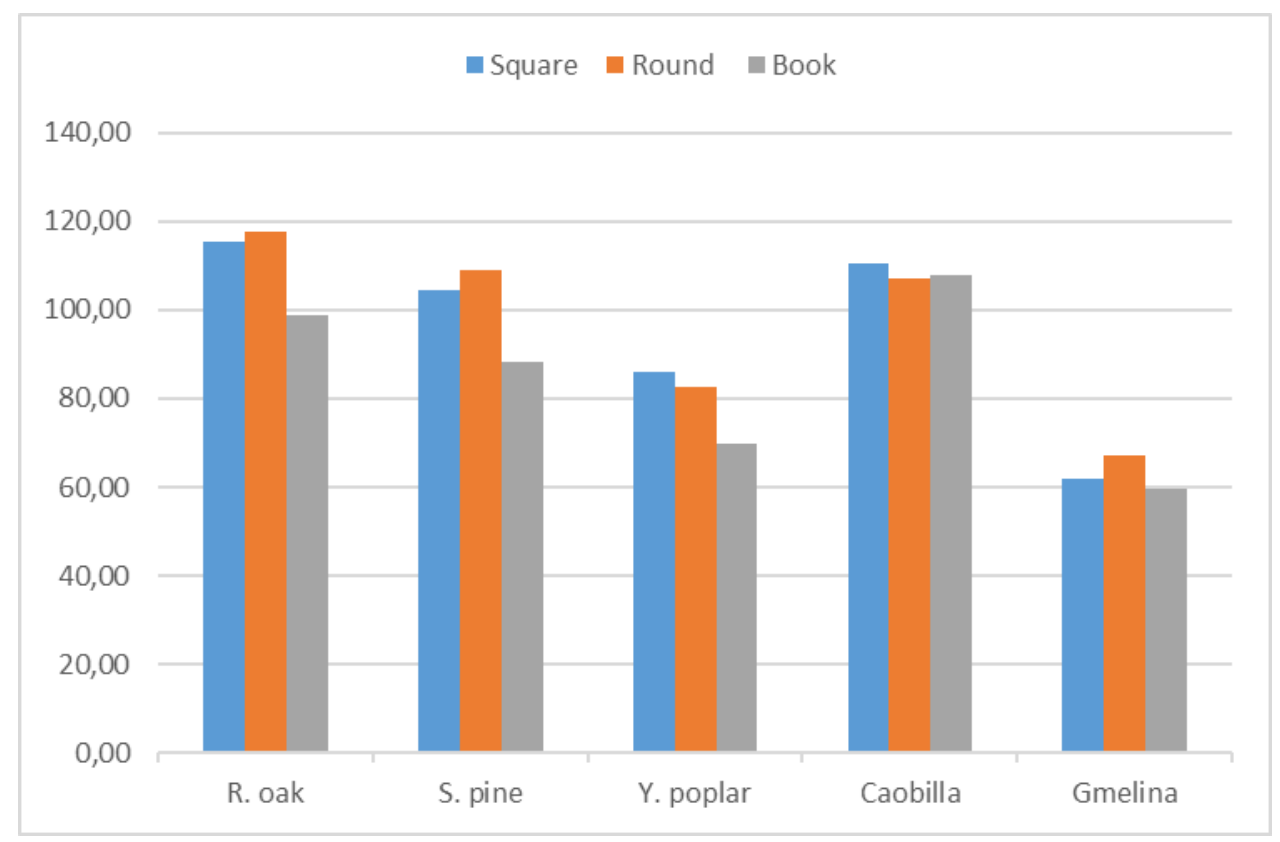

Figure 4. Comparison of modulus of rupture (MOR) values

Results are graphically represented in Figure 4. In general, there was a clear indication of a form factor of 1.18 from square to circular cross sections. Table 1 and Figure 4. clearly shows that ultimate bending strength values calculated for both square and circular cross-sections are nearly same. For the species of Red oak (Quercus rubra), Yellow poplar (Liriodendron tulipifera), and Southern pine (Pinus sp.), the test values were approximately 20 percent higher than the Wood Handbook (1987) values in the case of MOR, and approximately 10 percent higher in the case of specific gravity. However, in the case of Caobilla (Carapa guianensis) MOR and Specific gravity values were nearly same as the listed values. Furthermore, in the case of Gmelina (Gmelina arborea), MOR and specific gravity values were approximately 8 percent lower than the listed values. The ANOVA test was conducted and results were given in Table 2.

Table 2. Results of the ANOVA

\begin{tabular}{lcc}
\hline Source of Variation & $F$ & $P$-value \\
\hline Wood species & 38.18 & 0.000 \\
\hline Cross-section & 32.61 & 0.002 \\
\hline Interaction & 1.36 & 0.231 \\
\hline
\end{tabular}

In fact, as seen on Table 2, analysis of variance (ANOVA) showed that wood species and cross section factors were found statistically significant however, interaction between these factors were not found significant. LSD test was conducted to significant factors and results were given in Table 3 and Table 4.

Table 3. LSD test results of wood species factor

\begin{tabular}{ccc}
\hline \multirow{2}{*}{ Wood Species } & \multicolumn{2}{c}{ Maximum Bending Strength $\left(\mathrm{N} / \mathrm{mm}^{2}\right)$} \\
\cline { 2 - 3 } & \multicolumn{1}{c}{$\mathrm{X}$} & $\mathrm{HG}$ \\
\hline R. oak & 128.43 & $\mathrm{~A}$ \\
\hline Coabilla & 118.8 & $\mathrm{AB}$ \\
\hline S.pine & 113.96 & $\mathrm{~B}$ \\
\hline Y. poplar & 91.11 & $\mathrm{C}$ \\
\hline Gmelina & 69.51 & $\mathrm{D}$ \\
\hline
\end{tabular}


As it can be seen from the Table 3 that Red oak (Quercus rubra), was given the highest value in case of MOR while Gmelina (Gmelina arborea), has the lowest value with approximately $46 \%$ lower than Red oak.
Species of Coabilla (Carapa guianensis), S. pine Pinus sp.) and $\mathrm{Y}$. poplar (Liriodendron tulipifera), were followed to the Red oak specie respectively.

Table 4. LSD test results of cross-section factor

\begin{tabular}{ccc}
\hline \multirow{2}{*}{ Cross-Section } & \multicolumn{2}{c}{ Bending Strength $\left(\mathrm{N} / \mathrm{mm}^{2}\right)$} \\
\cline { 2 - 3 } & $X$ & $H G$ \\
\hline Circular & 115.81 & $\mathrm{~A}$ \\
\hline Square & 112.51 & $\mathrm{~A}$ \\
\hline Wood Handbook Value & 84.76 & $\mathrm{~B}$ \\
\hline
\end{tabular}

According to Table 4, both circular and square cross section specimens almost gave the similar results that higher approximately $27 \%$ than Wood Handbook (1999) values.

\section{Conclusions}

Evaluation of bending strength of five wood species showed that the materials used in this study had higher specific gravity and bending strength than what the books referred.

It was concluded that the 1.18 form factor, at least, is applicable within the scope of this study. However, since the sample sizes were small, it is reasonable to indicate that the results derived from this study is inconclusive in terms of finding the difference in bending strength between square and circular cross-section beams.

Overall, results of this study indicate that designers and furniture engineers may obtain good estimates from 1.18 form factor and comparison of MOR values and specific gravity of the wood species with the book values. This study is a preliminary study for the subject and future works should include investigating much wider spectrum of potential solutions to use of 1.18 form factor.

\section{References}

Addis, T., Buchanan, A.H., Walker, J.C.F., (1995). A comparison of density and stiffness for predicting wood quality or density: The lazy man's guide to wood quality. Journal of the Institute of Wood Science, 13(6), 539-543.

ASTM D 143-94, (2000). Standard methods for testing small clear specimens of timber. American Society for Testing and Materials, West Conshohocken, PA.

ASTM D 4442-92, (2001). Standard methods for testing for direct moisture content measurement of wood and wood-base materials. American Society for Testing and Materials, West Conshohocken, PA.

Chudnoff, M., (1984). Tropical Timbers of the World. Agricultural Handbook No.607, Madison WI: U.S. Department of Agriculture, Forest Service, Forest Products Laboratory. $464 \mathrm{pp}$.

Cown. D.J., (1992). Corewood (Juvenile Wood) in Pinus radiate - should we be concerned? New Zealand J. Forestry Sci. 22(1), 87-95.

Dinwoodie, J.M., (2000). Timber - Its Nature and Behavior. E \& FN Spon, Taylor \& Francis Group, London and New York.

Eckelman, C.A., Erdil, Y.Z., Haviarova, E., (2002). Effect of Cross Holes on the Strength of Chair and Table Legs. Forest Product journals, 52(5), 67-70.

Efe, H., Zhang, J., Erdil, Y.Z., Kasal, A., (2005). Moment Capacity of Traditional and Alternative T-Type End-to-SideGrain Furniture Joints. Forest Products Journal, 55(5), 69-73.

Erdil, Y.Z., Kasal, A., (2005). Bending Moment Capacity of Rectangular Mortise and Tenon Furniture Joints. Forest Products Journal 55(12), 209-213.

Harvald, C., Olesen, P.O., (1987). The variation of the basic density within the juvenile wood of Sitka spruce (Piceasitchensis). Scand. J. Forest Res. 2, 525-537.

Markwardt L.J., Wilson, T.R.C., (1935). Strength and Related Properties of Woods 
Grown in The United States: Technical Bulletin No: 479. U.S. Department of Agriculture, Forest Service, Forest Products Laboratory, $99 \mathrm{pp}$.

Newlin, J., Trayer, G., (1924). Form Factors of Beams Subjected to Transverse Loading, Rep. 181 to Nat. Advisory Committee for Aeronautics, Reprinted 1941 as Rep. 1310, Madison, WI: US. Department of Agriculture, Forest service Forest Products Laboratory.

Philips, E.W.J., (1941). The inclination of the fibrils in the cell wall and its relation to the compression strength of timber. Empire Forestry J. 20, 74-78.

Schniewind, A.P., (1989). Concise encyclopaedia of wood and wood-based materials. Pergamon Press. pp: 248.
Gen. Tech. Rept. FPL-GTR-113, (1999). Wood Handbook: Wood as an Engineering Material. USDA Forest Serv., Forest Prod. Lab., Madison, WI. $463 \mathrm{pp}$.

Wolfe, R., Bodig, J., Lebow P., (2001). Derivation of Nominal Strength for Wood Utility Poles, Gen. Tech. Rep. FPL-GTR128, Madison WI: U.S. Department of Agriculture, Forest Service, Forest Products Laboratory, $11 \mathrm{pp}$.

Walker, J.C.F., Butterfield, B.G., (1996). The importance of the microfibril angle for the processing industries. New Zealand Forestry, $\quad 40(3), \quad 34-40$. 